\title{
Modeling The Demand for inbound Tourism to Thailand: Panel Data Approach
}

\author{
Kittipat Preedatham ${ }^{1}$, Vorrapob Vivatvanit ${ }^{1}$, and Karoon Suksonghong ${ }^{2, *}$ \\ ${ }^{1}$ Department of Tourism and Hotel management, Faculty of Management and Tourism, Burapha University, \\ Thailand \\ ${ }^{2}$ Department of Accounting and Finance, Faculty of Engineering, Burapha University, Thailand \\ kittipat@buu.ac.th, vorrapob@buu.ac.th, and karoon@buu.ac.th
}

\begin{abstract}
This paper models the inbound tourism demand of Thailand by focusing on six major tourism markets, including China, Malaysia, South Korea, Japan, Russia, and India. Several economics variables widely used in the demand modeling literature were adopted. Besides, additional variables pertaining to environmental and security aspect were considered and incorporated into our investigated model. The panel data of six countries during 2003 and 2015 were collected from various sources. In our analysis, the random effects model was appropriated with the data set. The coefficient estimates were computed using panel least square method. Our results revealed that the substitute price of tourism destinations as well as the number of crime cases statistically significant in explaining the variation in tourism demand for Thailand. The major tourism markets of Thailand are sensitive the price of tourism and more likely to choose destination with lower costs of stay. Meanwhile, security and safety is another factor that influences their decision-making in selecting visiting destination.
\end{abstract}

Keywords: Modeling demand; International tourism; Pollution; Crime; Panel data

\section{INTRODUCTION}

Over the past decades, tourism industry became an importance sector in promoting economic growth for many developing countries. The United Nations World Tourism Organization (UNWTO) demonstrated that there are over 180 supply-side activities connected to tourism sector, including transportation, communication, accommodation, banking and finance, cultural, and promotion services. As a result, tourism industry not only generates income to the country but also provokes economic expansions by creating employment opportunity, investment in the new infrastructure, as well as, earing from foreign exchange (Archer, 1995; Durbarry, 2002; West, 1993). In the context of Thai economy, the Tourism Authority of Thailand (TAT) reported that tourism demand measured by the number of international tourist arrival increases from 13,822,000 to 32,588,000 during the period of 2006 to 2016. This substantial increase in the tourism demand stimulates many tourism-related activities that directly generate revenue for the country. In 2016, the World Travel and Tourism Council (WTTC) reported that the direct contribution of travel and tourism to Thailand's gross domestic product (GDP) was 1.29 billion Baht which accounts for only 9.2 percent of GDP.

Given the aforementioned fact, it is imperative to investigate the factors that influence demand for tourism. This is because such analysis can provide a policymaker invaluable information that could be used to facilitate the design of tourism focused policies that match with market demands (Song, Witt and $\mathrm{Li}, 2009)$. In addition, the informed policy formulation can help enhancing the optimal resources allocation. The need for tourism demand modeling has heralded the generation of numerous studies dedicated to the topic (Crouch, 1994a, 1994b; Johnson and Ashworth, 1990; Lim, 1997). However, these early studies have largely concentrated on examining tourism demand in the West. Meanwhile, studies on tourism demand in developing countries such as Thailand have received minor attention. Although, several studies attempted to model demand for Thailand's tourism (Chang, Sriboonchitta, \& 
Wiboonpongse, 2009; Song, Witt, \& Li, 2003; Vogt \& Wittayakorn, 1998), none of these studies have considered the impact of crime and environmental pollution on tourism demand in the country.

Kim and Wong (2006) demonstrated that tourism demand is directly affected by issues pertaining to security and health. This notion of insecurity is further aggravated by the persistent broadcasting of crime in the media that contributes towards an escalation in feelings of fear and insecurity (Garofalo, 1979). This will eventually impact negatively on tourist attitude toward safety of a destination. In general, potential tourists would avoid visiting a destination that lacks of public security and exhibits high crime records. Brunt, Mawby and Hambly (2000) also revealed that tourists are more likely to choose a less risky destination to travel since personal security is considered as one of important factors for selecting a tourism destination. Pizam (1999) and Ryan (1993) also explained that tourists are willing to cancel or postpone the trip or change to an alternative tourism destination if their booked destination is undergoing any insecurity issues.

Massidda and Etzo (2012) argued that quality of environment of the destination is another important element for selecting a tourism destination. Besides, Bigano, Hamilton and Tol (2006), Hamilton and Lau (2005) and Maddison (2001) reveal empirically that decision-making of tourists when choosing their travel destination is affected significantly by environmental related information. Greenough et al., (2001) exhibited that rain, strong winds, severe storms, floods, and poor air quality are negatively associated with comfort, health and safety of tourists.

It can be observed from the literature that the previous studies on tourism demand for Thailand have neglected the role of crime and environmental quality when modeling tourism demand. This study aims to address this gap by examining the role of crime and environmental quality in modeling the behavioral patterns of inbound tourists to Thailand. Specifically, this study investigates inbound tourism demand by incorporating environmental pollution and crime rate as new explanatory variables into the model. Based on the findings of this study, more effective and comprehensive policies can be designed to attract more genuine tourists to Thailand that will eventually accelerate economic growth and development.

In our analysis, inbound tourists are decomposed into sub-country level instead of using the aggregated number of tourist arrival to Thailand. Unlike the past studies (Chang et al., 2009; Song et al., 2003; Vogt \& Wittayakorn, 1998), we focus on the top six country that visited Thailand during the period of study. These countries consisting of China, Malaysia, South Korea, Japan, Russia, and India are regarded as the major tousim market for Thai economy. Therefore, the implications of the result of this focused analysis will help policy-maker to prepare concentrated marketing plan for promoting tourism in the efficient ways. Our analysis is conducted using panel data analysis technique that allows for heterogenous of characteristics among the countries of interest.

\section{LITERATURE REVIEW}

Modeling the demand for tourism is challenging due to the data available. However, its result can be contributed to policymakers to formulate the appropriate tourism policies. In the literature, it can be observed that empirical models employed for modeling tourism demand vary among researchers ranging from simple linear to sophisticated non-linear ones. According to the theory of consumer behavior and literature of tourism demand, the inbound tourism demand model for the Thai economy is suggested as follows:

$$
T A_{j t}=f\left(G D P_{j t}, P_{T H, j t}, P_{S U B, t}, P O L_{t}, C R_{t}\right)
$$

where $T A_{j t}$ is the number of tourist arrivals from origin country $j$ to Thailand. In this study, the origin country $j$ represents the top six tourism markets for Thailand, namely, China, Malaysia, South Korea, Japan, Russia, and India. GDP $P_{j t}$ is the real gross domestic product (GDP) for origin country $j . P_{T H, j t}$ is the price of tourism in Thailand adjusted by the USD-based exchange rate. As widely explained in the 
literature, price of tourism plays an important role in involving decision-making of either travelling or staying at home country. $P_{T H, j t}$ is computed by dividing the product of dividing CPI of Thailand with its own foreign exchange rate with the product dividing CPI of the origin country $j$ with its foreign exchange rate (Lim, 1997). Based on this calculation, it can be inferred that, the price of tourism in Thailand is a combination of relative prices and the nominal foreign exchange rate. It should be noted that the price of tourism reflects the cost of tourism activities in destination relative to the cost of tourism activities in the home country. Analogous to Song, Wong and Chon (2003) and Song et al. (2010), the price of tourism in Thailand can be mathematically expressed as:

$$
P_{T H, j t}=\frac{C P I_{T H} / F X_{T H}}{C P I_{j t} / F X_{j t}}
$$

where $C P I_{T H}$ and $C P I_{j t}$ represent the consumer price indices $(C P I)$ for Thailand and for the origin country $j$, respectively. $F X_{T H}$ is the foreign exchange rate between Thai Baht and the US dollar, whereas $F X_{j t}$ is the nominal foreign exchange rate between currency of the origin country $j$ and the US dollar.

According to the theory of consumer behavior, selecting the choice of tourism destination not only depends on the price of the destination itself, i.e. own price of tourism, but also on the price of alternative destinations, i.e. substitute price (Seetanah, Durbarry and Ragodoo, 2010; Song, Wong and Chon, 2003; Song, Witt and Jensen, 2003). Therefore, apart from the own price of tourism in Thailand, the substitute prices of tourism are also included in our model. Considering the geographical and cultural characteristics of countries in the neighboring region, this study selects Indonesia, Malaysia, Singapore, and Vietnam as the potential alternative tourism destinations of Thailand. In equation (1), the substitute price of tourism, i.e. $P_{S U B, t}$, is the weighted average price of tourism of the alternative destinations. According to the theory, the impact of the substitute price of tourism can either be positive or negative. A positive impact implies that the demand for tourism in Thailand increases as a result of an increase in the price of tourism in alternative destination. This is because tourists are more likely to switch from the higher cost tourism to the lower cost tourism destinations. In contrast, in the case that the coefficient of $P_{S U B, t}$ is negative, Indonesia, Malaysia, Singapore, and Vietnam are considered as the complementary destinations of Thailand. Similar to Gallet and Braun (2001) and Song, Wong and Chon (2003), the weighted average substitute price of tourism destination can be computed as follows:

$$
P_{S U B, t}=\sum_{k=1}^{4} \frac{C P I_{k t}}{E R_{k t}} w_{k t}
$$

where $k=1,2,3$, and 4 which represents 4 alternative tourism destinations, namely, Indonesia, Malaysia, Singapore, and Vietnam, respectively. $w_{k t}$ is the ratio of international tourist arrivals to country $k$ and the total international tourist arrivals of four countries. It can be calculated by $w_{k t}=T A_{k t} / \sum_{k=1}^{4} T A_{k t}$ where $T A_{k t}$ is the total international tourist arrival in country $k$.

Apart from the economic variables such as income and prices of tourism, pollution could have impact on satisfaction and choice of destination and period of visit (Bigano, Hamilton and Tol, 2006; Hamilton and Lau, 2005; Maddison, 2001). As a result, it can be suggested that, for tourists concerning their health, a country having higher level of pollution are less likely to be chosen as a visited destination. In our proposed model, $P O L_{j t}$ is defined as the level of air pollution in Thailand and is measured by metric tons per capita carbon dioxide, i.e. $\mathrm{CO}_{2}$, emissions. In addition, the presence of crime at the tourism destination also influences the number of international tourist arrivals. In the literature, Sönmez and Graefe (1998), Pizam (1999), and Brunt, Mawby and Hambly (2000) emphasized that tourists prefer destinations with high safety and securities because these two factors help reduce risk and danger. Besides, Garofalo (1979) 
argued that fear is not generated from the experience of crime, but also by reported crime news broadcasted through the media. Therefore, an increase in the crime case could rationally reduce the demand for tourism due to the fear and insecurity. In the demand model stated in equation (1), $C R_{t}$ refers to the number of crime case reported in Thailand which is used to measure the level of safety and security in Thailand.

\section{METHODS}

This study aims to examine the inbound international tourism demand in Thailand using balance panel data of six major tourism markets during 2003 and 2015. The major tourism markets of interest are China, Malaysia, South Korea, Japan, Russia, and India. Therefore, our panel data consists of 78 observations, i.e. six-country and 13-year. The data used in this study were extracted from the Bank of Thailand, World Development Indicators, Global Economics Monitor, Energy Information Administration, and Royal Thai Police databases. To induce stationary processes, some variables, such as, number of tourist arrival (TA), GDP, and number of crime case $(C R)$ were transformed into natural logarithm form.

\section{RESULT AND DISCUSSION}

In this section, the results from our analysis are reported and discussed. Since the data structure is panel data, we firstly determined whether fixed effects or random effects model was appropriate for our data set. The Hausman (1978) test for correlated random effects was conducted and the random effects estimator indicated that there was a random effects property in the data set. Therefore, our following analysis was done using random effects model. Table 1 reports the coefficient estimates together with their $t$-statistics. It should be noted that these coefficients were estimated using panel least square technique.

Table I. Result of estimation using panel least square

\begin{tabular}{lcc}
\hline Variables & Coefficient & $\boldsymbol{t}$-statistics \\
\hline $\ln \left(G D P_{j t}\right)$ & 0.086151 & 0.221487 \\
$P_{T H, j t}$ & -0.002064 & -0.057225 \\
$P_{S U B, t}$ & 1.345980 & $4.953472 * * *$ \\
$P O L_{t}$ & -0.113929 & -0.292439 \\
$\ln \left(C R_{t}\right)$ & -7.876865 & $-1.732646 *$ \\
\hline Remarks: & $\begin{array}{l}\text { Dependent variable is } \ln \left(T A_{j t}\right) \\
\end{array}$ & $* * *, * *, *$ indicate significant level at $1 \%, 5 \%$, and $10 \%$, respectively.
\end{tabular}

Apart from economics variables, the result exhibits that the coefficient of $\mathrm{POL}_{t}$ is negative meaning that air pollution has negative impact on tourism demand. An increase in $\mathrm{CO}_{2}$ emission would reduce demand for inbound tourism. Nevertheless, $t$-statistics shows that this variable is insignificant. Considering the impact of crime on tourism demand, it is reported that crime has an elastic negative impact on inbound tourism demand. The estimated coefficient is approximately -7.88 which imply that 1 percent increases in crime case will reduce demand for Thailand tourism around 7.88 percent. Our result is consistent with previous findings in the literature. For example, Brunt, Mawby and Hambly (2000) argued that the UK tourist will cancel the trip if she feels unsafe about the destination, regardless of how attractive the destination is. 
Neumayer (2004) reported that high crime rate creates negative perceptions about public security of a country.

\section{CONCLUSION}

Based on random-effects panel data analysis, this study examined the determinants of inbound tourism demand in Thailand. In addition to the use of economics variables, environmental and safety variables were considered and incorporated into the demand model. Our result reveals that demand for inbound tourism to Thailand was statistically explained by substitute price of tourism destination and crime case. We found that Indonesia, Malaysia, Singapore, and Vietnam are not complementary destination for Thailand. Thus, policy-maker should realize that promoting Thailand tourism individually may yield better result than promoting regional tourism as a whole. Besides, policy-maker should also monitor closely to the tourism price of these countries since the six-major tourist countries of Thailand are more likely to choose the destination with the lower price.

In addition, we also discovered that crime cases would reduce demand for tourism in Thailand. It is because the six-major tourist countries of Thailand seem to concern about safety and security when choosing a tourism destination. As a result, lowering the number of crime cases would help attracting international tourists. Thai government and the Royal Thai Police should initiate crime prevention strategies to reduce crime cases. Example of successful crime prevention strategies are widely discussed such as increasing frequency of police patrols, enhancing number and visibility of security personnel, implementing closed-circuit television (CCTV). By effective initiating and implementing any of these strategies, Thailand would become a secure and safe city that would eventually stimulate demand for Thailand tourism.

\section{REFERENCES}

Archer, Brian. (1995). Importance of tourism for the economy of Bermuda. Annals of Tourism Research, 22(4), 918-930.

Bigano, A., Hamilton, J., \& Tol, R.J. (2006). The impact of climate on holiday destination choice. Climatic Change, 76(3-4), 389-406.

Brunt, P., Mawby, R., \& Hambly, Z. (2000). Tourist victimisation and the fear of crime on holiday. Tourism Management, 21(4), 417-424.

Chang, Chia-Lin, Sriboonchitta, Songsak, \& Wiboonpongse, Aree. (2009). Modelling and forecasting tourism from East Asia to Thailand under temporal and spatial aggregation. Mathematics and Computers in Simulation, 79(5), 1730-1744.

Crouch, G.I. (1994a). The study of international tourism demand: A review of findings. Journal of Travel Research, 33(1), 12-23.

Crouch, G.I. (1994b). The study of international tourism demand: A survey of practice. Journal of Travel Research, 32(4), 41-55.

Durbarry, Ramesh. (2002). The Economic Contribution of Tourism in Mauritius. Annals of Tourism Research, 29(3), 862-865.

Gallet, C.A., \& Braun, B.M. (2001). Gradual switching regression estimates of tourism demand. Annals of Tourism Research, 28(2), 503-508.

Garofalo, J. (1979). Victimization and the fear of crime. Journal of Research in Crime and Delinquency, 16(1), 80-97.

Greenough, G., McGeehin, M., Bernard, S.M., Trtanj, J., Riad, J., \& Engelberg, D. (2001). The potential impacts of climate variability and change on health impacts of extreme weather events in the United States. Environmental Health Perspectives, 109, 191-198. 
Hamilton, J.M., \& Lau, M.A. (2005). The role of climate information in tourist destination choice decision-making. In S. Gössling and M.C. Hall (Eds.), Tourism and Global Environmental Change. London: Routledge.

Hausman, J. A. (1978). Specification tests in econometrics. Econometrica: Journal of the econometric society, 1251-1271.

Johnson, P., \& Ashworth, J. (1990). Modelling tourism demand: A summary review. Leisure Studies, 9(2), 145-161.

Kim, S. S., \& Wong, Kevin K. F. (2006). Effects of News Shock on Inbound Tourist Demand Volatility in Korea. Journal of Travel Research, 44(4), 457-466

Lim, C. (1997). Review of international tourism demand models. Annals of Tourism Research, 24(4), 835-849.

Massidda, C., \& Etzo, I. (2012). The determinants of Italian domestic tourism: A panel data analysis. Tourism Management, 33(3), 603-610.

Maddison, D. (2001). In search of warmer climates? The impact of climate change on flows of British tourists. Climatic Change, 49(1-2), 193-208.

Neumayer, E. (2004). The impact of political violence on tourism: Dynamic cross national estimation. Journal of Conflict Resolution, 48(2), 259-281.

Pizam, A. (1999). A comprehensive approach to classifying acts of crime and violence at tourism destinations. Journal of Travel Research, 38(5), 5-12.

Ryan, C. (1993). Crime, violence, terrorism and tourism: An accidental or intrinsic relationship? Tourism Management, 14(3), 173-183.

Seetanah, B., Durbarry, R., \& Ragodoo, J.F.N. (2010). Using the panel cointegration approach to analyse the determinants of tourism demand in South Africa. Tourism Economics, 16(3), 715-729.

Song, H., Witt, S.F., \& Li, G. (2003). Modelling and forecasting the demand for Thai tourism. TourismEconomics, 9(4), 363-387.

Song, H., Wong, K.K.F., \& Chon, K.K.S. (2003). Modelling and forecasting the demand for Hong Kong tourism. International Journal of Hospitality Management, 22(4), 435-451.

Song, H., Li, G., Witt, S.F., \& Fei, B. (2010). Tourism demand modelling and forecasting: How should demand be measured? Tourism Economics, 16(1), 63-81.

Song, H., Witt, S.F., \& Li, G. (2009). The Advanced Econometrics of Tourism Demand. London: Routledge.

Sönmez, S.F., \& Graefe, A.R. (1998). Influence of terrorism risk on foreign tourism decisions. Annals of Tourism Research, 25(1), 112-144.

Vogt, Michael G., \& Wittayakorn, Chutima. (1998). Determinants of the demand for Thailand's exports of tourism. Applied Economics, 30(6), 711-715.

West, Guy R. (1993). Economic significance of tourism in Queensland. Annals of Tourism Research, 20(3), 490-504. 